\title{
Características da carcaça de novilhos não-castrados ou castrados terminados em confinamento e abatidos aos 16 ou 26 meses de idade ${ }^{1}$
}

\author{
Fernando Kuss ${ }^{2}$, Jorge López ${ }^{3}$, Júlio Otávio Jardim Barcellos ${ }^{3}$, João Restle ${ }^{4}$, José Luiz \\ Moletta $^{5}$, Daniel Perotto 5
}

\footnotetext{
${ }^{1}$ Pesquisa financiada com recursos do Conselho Nacional de Desenvolvimento Científico e Tecnológico (Projeto Universal 472631/2004-7) e do Instituto Agronômico do Paraná.

2 Departamento de Zootecnia da Universidade Tecnológica Federal do Paraná - Campus Dois Vizinhos, Estrada para Boa Esperança, Km 04, CEP: 85660-000, Dois Vizinhos - PR.

${ }^{3}$ Departamento de Zootecnia da Universidade Federal do Rio Grande do Sul.

${ }^{4}$ Departamento de Produção Animal da Universidade Federal de Goiás.

5 Programa de Produção Animal do Instituto Agronômico do Paraná.
}

RESUMO - Realizou-se este trabalho para avaliar as características de carcaça de novilhos castrados ou não-castrados terminados em confinamento e abatidos aos 16 (superjovem) ou 26 (jovem) meses de idade. A dieta, com relação volumoso:concentrado de 50:50, continha 11,8\% de proteína bruta e 2,83 Mcal de energia digestível $/ \mathrm{kg}$ de matéria seca Novilhos não-castrados, independentemente da categoria, apresentaram carcaças mais pesadas. A diferença de peso da carcaça entre animais não-castrados e castrados superjovens (14\%) foi mais evidente que nos animais jovens (33\%). A espessura de gordura subcutânea (EGS) na categoria superjovem foi similar entre animais não-castrados e castrados $(5,17$ e 4,54 mm), ao passo que, na categoria jovem, as carcaças dos não-castrados apresentaram menor EGS (2,90 vs 4,72 mm) Melhor conformação (15,16 vs 14,12 pontos), maior área do músculo Longissimus dorsi (86,96 vs $\left.72,66 \mathrm{~cm}^{2}\right)$ e maiores comprimentos de carcaça $(134,70$ vs $125,86 \mathrm{~cm})$ e perna $(69,09$ vs $65,28 \mathrm{~cm})$ foram observados nas carcaças dos animais não-castrados. Carcaças de animais não-castrados apresentaram maior porcentagem de músculo (62,70 vs $58,40 \%)$ e menor de gordura (22,60 vs 27,01\%) em comparação a carcaças de animais castrados, o que resultou em cortes cárneos mais magros nos animais não-castrados, com maior relação músculo:gordura (3,25 vs 2,74).

Palavras-chave: categoria animal, condição sexual, conformação da carcaça, espessura de gordura, gordura, músculo

\section{Carcass characteristics of intact or castrated feedlot-finished males slaughtered at 16 or 26 months of age}

\begin{abstract}
The objective of this experiment was to evaluate the carcass characteristics of intact or castrated feedlotfinished males slaughtered at 16 (young steers) or 26 months of age (steers). The diet, with $50 \%$ roughage and $50 \%$ concentrate, contained $11.8 \%$ of crude protein and 2.83 Mcal of digestible energy $/ \mathrm{kg}$ of dry matter. Intact males from both categories showed heavier carcasses. The weight difference between intact and castrated males was more evident for 26-month-old steers (33\%) than for 16-month-old (14\%) animals. Carcass subcutaneous fat thickness (SFT) was similar for 16-month-old intact and castrated males $(5.17$ and $4.54 \mathrm{~mm})$, while for 26 -month-old males, the SFT was lower for intact males than for castrated males (2.90 vs $4.72 \mathrm{~mm}$ ). Better conformation (15.16 vs 14.12 points), larger Longissimus dorsi area $\left(86.96\right.$ vs $\left.72.66 \mathrm{~cm}^{2}\right)$ and longer carcass $(134.70 \mathrm{~cm})$ and leg $(69.09 \mathrm{~cm})$ length were observed for intact male carcasses. Intact male carcasses had higher muscle percentage (62.70 vs $58.40 \%)$ and lower fat percentage $(22.60$ vs $27.01 \%)$ than castrated male carcasses, resulting in cuts with more lean and higher muscle:fat ratio (3.25 vs 2.74 ).
\end{abstract}

Key Words: animal category, carcass conformation, fat, fat thickness, muscle, sex condition

\section{Introdução}

Entre produtores e pesquisadores no âmbito da produção de bovinos de corte é consenso que a redução da idade de abate dos 26 para os 16 meses de idade intensifica a produção na propriedade, tornando-a mais eficiente em produção de alimento de qualidade e gerenciamento de recursos financeiros. Essa intensificação ocorre principalmente em razão das taxas de ganho de peso do nascimento (30 $\mathrm{kg}$ de peso vivo) ao abate (450 $\mathrm{kg}$ de peso vivo), que variam de $540 \mathrm{~g} / \mathrm{animal} / \mathrm{dia}$ no sistema de abate aos 26 meses (jovem) a $875 \mathrm{~g} /$ animal/dia para animais abatidos aos 
16 meses (superjovens). Restle \& Vaz (2003) descreveram economia de energia de $45 \%$ na produção de novilhos superjovens (1.090 kg NDT/animal) em comparação aos jovens (1.917 kg de NDT/animal).

Embora a redução da idade de abate resulte em maior economia de energia, giro mais rápido de capital na propriedade e liberação de áreas pastoris para outras categorias (Restle \& Vaz, 2003), pesquisas recentes têm comprovado que a carcaça proveniente de animais jovens é mais desejada pelo frigorífico por apresentar maior participação do corte serrote, mais valorizado comercialmente (Pacheco et al., 2005a). A carcaça do animal jovem é também mais desejada pelo consumidor final, que prefere adquirir cortes cárneos com maior relação músculo:gordura, menor quantidade de lipídios e excelente maciez, similar à da carne de animais superjovens (Pacheco et al., 2005b).

A terminação de animais não-castrados ao abate nas regiões Centro-Oeste e Norte do Brasil é uma prática comum entre produtores, por melhorar a conformação (expressão muscular) da carcaça, principalmente em rebanhos com genes Bos indicus. Existem na literatura científica informações sobre a vantagem de animais não-castrados, em comparação aos castrados, quanto à eficiência biológica de transformar alimento em ganho de peso (Gerrard et al., 1987; Restle et al., 1994; Restle et al., 2000a; Restle \& Vaz, 2003). Entretanto, os resultados descritos para características de carcaça são contraditórios, possivelmente em razão do nível de energia da dieta (Dikeman et al., 1986; Restle et al., 1996) e da fase de crescimento estudada (Müller \& Restle, 1983; Morgan et al., 1993a; Restle et al., 1994; Restle \& Vaz, 1997; Restle et al., 2000b; Purchas et al., 2002).

Neste trabalho objetivou-se avaliar as características quantitativas da carcaça de novilhos não-castrados ou castrados das categorias jovem (para abate aos 26 meses de idade) e superjovem (para abate aos 16 meses de idade, respectivamente) terminados em confinamento.

\section{Material e Métodos}

O experimento foi conduzido na Estação Experimental Fazenda Modelo do Instituto Agronômico do Paraná - FM/ IAPAR, situada no município de Ponta Grossa, região centro-sul do estado.

Utilizaram-se 32 novilhos não-castrados ou castrados, do grupo genético $1 / 2$ Purunã (igual proporção de sangue Angus, Charolês, Caracu e Canchim) $+1 / 2$ Canchim. No grupo de animais castrados, a extirpação dos testículos dos animais foi realizada a faca, aos 7 meses de idade. Os animais não-castrados ou castrados foram distribuídos em dois grupos, de acordo com a idade de abate: 16 meses (superjovem) ou 26 meses (jovem) de idade. Ao início do período experimental, os animais não-castrados e castrados do sistema superjovem apresentavam na média 230,0 e $203,5 \mathrm{~kg}$ e os do sistema jovem, não-castrados e castrados, 301,5 e $264,5 \mathrm{~kg}$. O escore da condição corporal inicial foi de 2,7 e 2,8 pontos; 3,0 e 2,9 pontos, respectivamente, segundo classificação proposta por Lowman et al. (1973), em que 1 = muito magro e $5=$ muito gordo. A idade inicial dos animais superjovens e jovens foi de 9 e 22 meses, respectivamente. O baixo peso inicial dos animais provavelmente esteve relacionado à baixa disponibilidade $\mathrm{e}$ qualidade da pastagem em que foram mantidos no período anterior ao início do trabalho, ocasionado por um longo período de seca.

Os animais foram mantidos em confinamento, com uma dieta contendo $11,8 \%$ de proteína bruta e 2,83 Mcal de energia digestível/kg de matéria seca (MS), composta de $50 \%$ de volumoso (silagem de milho) e $50 \%$ de concentrado contendo $73,0 \%$ de milho grão, $25 \%$ de farelo de soja, $1 \%$ sal comum e $1 \%$ de calcário calcítico, com base na MS.

O sacrifício dos animais foi pré-estipulado com base na condição corporal (entre 3,5 e 4,0 pontos), visando grau de acabamento preconizado pelos frigoríficos (com espessura de gordura subcutânea de 3 a 6 mm). O estado corporal foi incluído no modelo matemático como co-variável. À medida que a média dos lotes atingiu o escore corporal preconizado, os animais foram submetidos a jejum de sólidos de 16 horas na fazenda, pesados e transportados em caminhão boiadeiro por $10 \mathrm{~km}$ até o frigorífico comercial, onde foram abatidos, após o descanso mínimo de 24 horas, conforme fluxo de abate normal do estabelecimento.

No fim da linha de abate, as duas meias-carcaças foram lavadas, identificadas e pesadas e, em seguida, foram colocadas em câmara fria, a $0^{\circ} \mathrm{C}$, por 24 horas. Depois de resfriadas, as carcaças foram pesadas e avaliadas quanto à conformação, baseada na expressão muscular: 1-3 pontos = inferior; $4-6$ pontos $=$ má; $7-9$ pontos $=$ regular; $10-12$ pontos $=$ boa; $13-15$ pontos $=$ muito boa; $16-18=$ superior; segundo metodologia descrita por Müller (1987). O rendimento de carcaça quente, expresso em percentual, foi obtido pela relação entre o peso de carcaça quente e o peso registrado na fazenda.

Na meia-carcaça direita, foram tomadas primeiramente as medidas métricas, como comprimento de carcaça, correspondente à medida do bordo anterior do osso púbis ao bordo anterior medial da primeira costela; e espessura de coxão, medida com auxílio de compasso posicionado entre a face lateral e a medial da porção superior do coxão. Um 
corte horizontal foi realizado entre a $12 \underline{a}$ e a $13 \underline{a}$ costelas da meia-carcaça direita com a finalidade de expor o músculo Longissimus dorsi para a aferição da área desse músculo, com auxílio de planímetro. No mesmo local, foi medida a espessura de gordura subcutânea, obtida pela média aritmética de duas observações.

A composição física da carcaça foi analisada em uma seção da $10^{\mathrm{a}}-11^{\mathrm{a}}-12^{\mathrm{a}}$ costelas, extraída segundo metodologia proposta por Hankins \& Howe (1946), adaptada por Müller (1973), na qual foi determinada a composição em músculo = $15,56+0,81 ;$ gordura $=3,06+0,82 ;$ e osso $=4,30+0,61$, obtida conforme metodologia descrita por Hankins \& Howe (1946).

O delineamento experimental utilizado foi o inteiramente casualizado. A análise estatística foi realizada com auxílio do programa SAS (2000) e os dados foram submetidos à análise de normalidade pelo teste Shapiro-Wilk. As variáveis que apresentaram distribuição normal foram submetidas à análise de variância e o modelo proposto foi analisado pelo procedimento GLM. As variáveis que não apresentaram distribuição normal foram analisadas utilizando-se a metodologia de Modelos Lineares Generalizados, pelo procedimento GENMOD, utilizando-se a distribuição gama.
O modelo estatístico utilizado foi:

$$
\mathrm{Y}_{\mathrm{ijk}}=\mu+\mathrm{C}_{\mathrm{i}}+\mathrm{S}_{\mathrm{j}}+\mathrm{CS}_{\mathrm{ij}}+\mathrm{CCF}_{\mathrm{k}}+\mathrm{E}_{\mathrm{ijk}}
$$

em que: $\mathrm{Y}_{\mathrm{ijk}}=$ variáveis dependentes; $\mu=$ média de todas as observações; $\mathrm{C}_{\mathrm{i}}=$ efeito da i-ésima categoria animal, em que: $i=$ jovem ou superjovem; $S_{j}=$ efeito da j-ésima condição sexual, em que $\mathrm{j}=$ não-castrado ou castrado; $\mathrm{CS}_{\mathrm{ij}}=$ efeito da interação categoria animal $\times$ condição sexual; $\mathrm{CCF}_{\mathrm{k}}=$ efeito da co-variável condição corporal final; e $\mathrm{E}_{\mathrm{ijk}}=$ erro aleatório associado a cada observação.

As médias foram comparadas pelo método dos quadrados mínimos (LSMEANS) a 5\% de significância e as variáveis dependentes foram submetidas à análise de correlação.

\section{Resultados e Discussão}

O peso de abate, o peso de carcaça quente, a espessura de gordura subcutânea (EGS) e a espessura de gordura subcutânea ajustada para $100 \mathrm{~kg}$ de carcaça foram influenciados de forma significativa pela interação categoria $\times$ condição sexual (Tabela 1). Os pesos de abate e de carcaça dos animais não-castrados foram superiores aos dos castrados em ambas as categorias. Comportamento similar foi registrado em estudos de Restle et al. (1994) e Restle et al. (2000b) para animais abatidos aos 24-26 meses de idade e

Tabela 1 - Peso de abate, peso e rendimento de carcaça quente, espessura de gordura subcutânea e quantidade de gordura de toalete de novilhos jovens e superjovens

\begin{tabular}{|c|c|c|c|}
\hline \multirow[t]{2}{*}{ Condição sexual } & \multicolumn{2}{|c|}{ Categoria } & \multirow[t]{2}{*}{ Média } \\
\hline & Jovem & Superjovem & \\
\hline \multicolumn{4}{|c|}{ Peso de abate, $\mathrm{kg}$} \\
\hline Não-castrados & $578,40 \pm 14,13 a$ & $504,11 \pm 18,88 b$ & $541,26 \pm 10,21$ \\
\hline Média & $516,24 \pm 13,69$ & $470,48 \pm 14,63$ & \\
\hline Castrado & $255,75 \pm 13,04 b c$ & $253,83 \pm 11,33 \mathrm{c}$ & $254,79 \pm 6,64$ \\
\hline Não-castrados & $340,09 \pm 9,49 a$ & $290,55 \pm 12,68 b$ & $315,32 \pm 13,04$ \\
\hline Média & $297,92 \pm 9,20$ & $272,55 \pm 9,83$ & \\
\hline \multicolumn{4}{|c|}{ Rendimento de carcaça quente, $\%$} \\
\hline Castrado & $56,29 \pm 1,12$ & $58,08 \pm 0,98$ & $57,18 \pm 0,57$ \\
\hline \multicolumn{4}{|c|}{ Espessura de gordura subcutânea, $\mathrm{mm}$} \\
\hline Não-castrados & $2,90 \pm 0,41 b$ & $5,17 \pm 0,56 a$ & $4,04 \pm 0,30$ \\
\hline Média & $3,81 \pm 0,40$ & $4,86 \pm 0,43$ & \\
\hline \multicolumn{4}{|c|}{ Espessura de gordura subcutânea $/ 100 \mathrm{~kg}$ de peso de carcaça quente, $\mathrm{mm}$} \\
\hline Castrado & $1,96 \pm 0,23 \mathrm{a}$ & $1,71 \pm 0,20 \mathrm{a}$ & $1,84 \pm 0,12$ \\
\hline Não-castrados & $0,88 \pm 0,17 \mathrm{~b}$ & $1,73 \pm 0,22 \mathrm{a}$ & $1,31 \pm 0,12$ \\
\hline Média & $1,43 \pm 0,16$ & $1,72 \pm 0,17$ & \\
\hline
\end{tabular}

a, b, c Médias seguidas de letras minúsculas diferentes para mesma característica diferem $(\mathrm{P}<0,05)$ pelo teste $\mathrm{t}$. 
também por Restle \& Vaz (1997) em animais abatidos aos 14-16 meses de idade.

O peso de carcaça quente acompanhou o comportamento do peso de abate e a correlação entre estas variáveis foi de $\mathrm{r}=0,97(\mathrm{P}<0001)$. Os pesos de carcaça dos animais utilizados neste estudo foram superiores ao peso em geral exigido pelos frigoríficos (mínimo de 15@ou $225 \mathrm{~kg}$ ).

A diferença do peso de abate e de carcaça entre jovens não-castrados e castrados foi de 27 e $33 \%$ e, entre os superjovens não-castrados e castrados, de 15 e 14\%, respectivamente. A diferença nos pesos de abate e de carcaça entre os estados sexuais foi mais acentuada na categoria jovem.

No início do confinamento, a vantagem no peso dos animais não-castrados sobre os castrados foi semelhante, de $14 \%$ para os jovens e $13 \%$ para os superjovens. Nos animais superjovens, a diferença percentual no peso final favorável aos não-castrados foi semelhante à observada no início do confinamento. Entretanto, nos jovens a diferença percentual no peso final, que foi maior nos animais nãocastrados, foi bem mais acentuada que a verificada no início do confinamento. A principal causa dessa diferença nos pesos de abate e de carcaça deve-se ao peso mais elevado dos animais não-castrados no início do experimento $(230,0$ vs $203,5 \mathrm{~kg}$ ) e ao período de confinamento desses animais (264 vs 257 dias), que foi mais prolongado que o dos animais castrados na categoria jovem $(301,5$ vs $264,5 \mathrm{~kg}$; 194 vs 146 dias). Os animais jovens não-castrados levaram mais tempo em confinamento para atingir o grau de acabamento mínimo preconizado.

As médias registradas para o rendimento de carcaça dos animais deste estudo podem ser consideradas elevadas (média 57,7\%), resultado do jejum pré-abate prolongado (16 horas na fazenda +24 horas no frigorífico). O rendimento de carcaça não foi influenciado pela categoria ou condição sexual dos animais. Semelhanças no rendimento de carcaça entre não-castrados e castrados são relatadas para animais das categorias superjovem (Restle \& Vaz, 1997) e jovem (Restle et al., 2000b). Compilando resultados de estudos sobre características de carcaça de animais superjovens e jovens, Restle \& Vaz (2003) verificaram semelhança de rendimento de carcaça entre estas categorias (53,9 e 54,3\%, respectivamente). Pacheco et al. (2005a), comparando animais castrados das duas categorias abatidos com peso similar, porém com espessura de gordura subcutânea maior nos superjovens, não observaram diferença no rendimento de carcaça.

$\mathrm{Na}$ categoria superjovem, a espessura de gordura subcutânea foi similar entre animais não-castrados e castrados, porém, na categoria jovem, foi menor nos animais não- castrados. A espessura de gordura subcutânea inicialmente pretendida foi de 3 a $6 \mathrm{~mm}$ (exigência dos frigoríficos em geral), no entanto, nos animais jovens não-castrados, foi 2,9 $\mathrm{mm}$ (levemente abaixo do limite inferior pretendido) e, nas demais categorias, foi similar e dentro da amplitude pretendida.

Em comparação aos castrados, os animais jovens nãocastrados permaneceram 48 dias a mais no confinamento e apresentaram elevado peso de abate $(578,40$ vs $454,09 \mathrm{~kg})$ e de carcaça $(340,09$ vs $255,75 \mathrm{~kg})$ e, mesmo assim, tiveram menor espessura de gordura subcutânea.

A superioridade do acabamento da carcaça dos animais jovens castrados em relação aos jovens não-castrados possivelmente se deve à menor exigência de mantença dos animais jovens castrados, que apresentaram menor peso corporal durante a terminação no confinamento. Além disso, embora sem diferença significativa, os animais jovens não-castrados apresentaram maior volume $(\mathrm{kg})$ de órgãos vitais e trato gastrintestinal (28,8 e 18,6\%, respectivamente) em comparação aos jovens castrados (Kuss et al., 2008). Considerando relatos de Caton \& Dhuyvetter (1997) de que, em ruminantes adultos, a maior parte da energia utilizada para mantença é utilizada pelas vísceras, e considerando ainda informações de Smith \& Baldwin (1973) de que órgãos como coração, fígado e sistema gastrintestinal são os tecidos de maior atividade metabólica nos animais, pode-se pressupor que, neste estudo, os animais jovens castrados puderam canalizar maior quantidade de energia consumida para deposição tecidual corporal, entre elas, a gordura subcutânea. Restle et al. (1994) e Restle et al. (2000b) também observaram melhor acabamento da carcaça dos animais castrados em relação aos não-castrados, quando abatidos aos 24-26 meses de idade.

Nos animais superjovens, a diferença em volume de órgãos vitais e trato gastrintestinal (10,3 e 5,7\%, respectivamente) entre castrados e não-castrados foi inferior, o que explica a semelhança entre os valores de acabamento na carcaça entre estes grupos. Restle \& Vaz (1997) avaliaram as características quantitativas de animais castrados ou não-castrados alimentados em confinamento com relação volumoso:concentrado de 55:45 (próxima à relação volumoso:concentrado utilizado neste estudo, 50:50) e abatidos aos 14 meses de idade e também não observaram diferenças na espessura de gordura subcutânea entre os grupos (5,98 e 4,95 mm, respectivamente). Arthaud et al. (1977) estudaram o comportamento das características da carcaça de novilhos não-castrados ou castrados submetidos a dois níveis de alimentação (alto e baixo) e verificaram que, no nível de alimentação alto, não houve diferença na 
espessura de gordura subcutânea entre animais nãocastrados e castrados, independentemente da idade de abate (12, 15 ou 18 meses).

Existe certa resistência por parte dos frigoríficos em abater animais não-castrados, pois normalmente esses animais apresentam escasso acabamento, o que provoca o escurecimento dos músculos externos da carcaça durante o resfriamento, prejudicando o aspecto visual e intensificando as perdas de líquidos da carcaça, reduzindo o preço pago por kg de carcaça no atacado. No entanto, geralmente os animais não-castrados abatidos nos frigoríficos são touros de descarte com idade superior a 24 meses.

Os valores obtidos para a musculosidade da carcaça, como conformação, espessura de coxão, área de olho-delombo e área de olho-de-lombo/100 kg peso de carcaça quente, foram similares entre jovem e superjovem (Tabela 2) e indicam conformação das carcaças muito boa em ambas as categorias. Valores inferiores e similares de conformação entre as categorias jovem (10,58 pontos) e superjovem
(10,75 pontos) foram observados por Pacheco et al. (2005a) em novilhos da terceira geração do cruzamento Charolês $\times$ Nelore terminados em confinamento. Entretanto, relatos indicam redução de conformação com o avanço da idade. Towsend et al. (1990), em pesquisa com novilhos de 2 e 3 anos de idade, e Vaz et al. (2002), com novilhos e vacas de descarte, descreveram carcaças com menor expressão muscular dos animais mais velhos. Neste estudo a melhor conformação da carcaça foi observada nos animais nãocastrados.

Superioridade de animais não-castrados em relação aos castrados para conformação também foi relatada por outros autores (Arthaud et al., 1977; Müller \& Restle, 1983; Restle et al., 1996; Restle \& Vaz, 1997; Restle et al., 2000b). Maior área de olho-de-lombo foi registrada nos animais nãocastrados, porém, esta vantagem deixou de existir quando essa característica foi ajustada para $100 \mathrm{~kg}$ de carcaça, o que indica desaceleração do crescimento desse músculo com o desenvolvimento dos animais.

Tabela 2 - Conformação de carcaça, espessura de coxão, área de olho-de-lombo e comprimentos de carcaça e perna de novilhos jovens e superjovens

\begin{tabular}{|c|c|c|c|}
\hline \multirow[t]{2}{*}{ Condição sexual } & \multicolumn{2}{|c|}{ Categoria } & \multirow[t]{2}{*}{ Média } \\
\hline & Jovem & Superjovem & \\
\hline \multicolumn{4}{|c|}{ Conformação, pontos } \\
\hline Castrados & $13,18 \pm 0,69$ & $15,08 \pm 0,60$ & $14,12 \pm 0,35 \mathrm{~B}$ \\
\hline Não-castrados & $15,01 \pm 0,50$ & $15,31 \pm 0,67$ & $15,16 \pm 0,36 \mathrm{~A}$ \\
\hline Média & $14,00 \pm 0,48$ & $15,19 \pm 0,52$ & \\
\hline \multicolumn{4}{|c|}{ Espessura de coxão, cm } \\
\hline Castrados & $27,14 \pm 0,83$ & $27,57 \pm 0,72$ & $27,36 \pm 0,42$ \\
\hline Não-castrados & $29,06 \pm 0,61$ & $27,42 \pm 0,81$ & $28,24 \pm 0,44$ \\
\hline Média & $28,10 \pm 0,59$ & $27,50 \pm 0,63$ & \\
\hline \multicolumn{4}{|c|}{ Área de olho-de-lombo, $\mathrm{cm}^{2}$} \\
\hline Castrados & $71,72 \pm 5,74$ & $73,60 \pm 4,99$ & $72,66 \pm 2,93 \mathrm{~B}$ \\
\hline Não-castrados & $93,01 \pm 4,18$ & $80,90 \pm 5,58$ & $86,96 \pm 3,02 \mathrm{~A}$ \\
\hline Média & $82,37 \pm 4,05$ & $77,25 \pm 4,33$ & \\
\hline \multicolumn{4}{|c|}{ Área de olho-de-lombo/100 kg peso de carcaça quente, $\mathrm{cm}^{2}$} \\
\hline Castrados & $27,92 \pm 1,68$ & $29,27 \pm 1,46$ & $28,60 \pm 0,86$ \\
\hline Não-castrados & $27,22 \pm 1,22$ & $28,02 \pm 1,63$ & $27,62 \pm 0,88$ \\
\hline Média & $27,57 \pm 1,18$ & $28,64 \pm 1,27$ & \\
\hline \multicolumn{4}{|c|}{ Comprimento de carcaça, $\mathrm{cm}$} \\
\hline Castrados & $124,96 \pm 1,59$ & $126,75 \pm 1,38$ & $125,86 \pm 0,81 \mathrm{~B}$ \\
\hline Não-castrados & $134,88 \pm 1,16$ & $134,52 \pm 1,55$ & $134,70 \pm 0,84 \mathrm{~A}$ \\
\hline Média & $129,92 \pm 1,12$ & $130,64 \pm 1,19$ & \\
\hline \multicolumn{4}{|c|}{ Comprimento de perna, $\mathrm{cm}$} \\
\hline Castrados & $64,19 \pm 1,46 b$ & $66,36 \pm 1,27 b$ & $65,28 \pm 0,75$ \\
\hline Não-castrados & $70,46 \pm 1,07 a$ & $67,72 \pm 1,42 \mathrm{ab}$ & $69,09 \pm 0,77$ \\
\hline Média & $67,33 \pm 1,03$ & $67,04 \pm 1,10$ & \\
\hline
\end{tabular}

A, B Médias seguidas por letras maiúsculas diferentes na coluna, para mesma característica, diferem $(\mathrm{P}<0,05)$ pelo teste $\mathrm{F}$.

a, b Médias seguidas por letras minúsculas diferentes, para mesma característica, diferem $(\mathrm{P}<0,05)$ pelo teste t. 
A correlação da conformação e da área de olho-delombo com a quantidade de músculo na carcaça foi de 0,42 ( $\mathrm{P}=0,0141)$ e de $0,81(\mathrm{P}<0,0001)$, respectivamente. No estudo de Morgan et al. (1993b), comparando animais não-castrados e castrados confinados a partir dos 7 meses de idade e abatidos em intervalos de 42 dias, os autores descreveram que, independentemente do período de confinamento, os animais não-castrados apresentaram maiores taxas de síntese e menores taxas de degradação de proteína no tecido muscular esquelético, o que explica o aumento da área de olho-de-lombo nos animais não-castrados. Nos estudos de Champagne et al. (1969), Morais et al. (1993), Restle et al. (1996), Restle Vaz (1997) e Vaz et al. (2001), também foi descrito maior valor de área de olho-de-lombo nos animais não-castrados, no entanto, quando o peso foi ajustado para $100 \mathrm{~kg}$ de carcaça, essa diferença deixou de existir.

O comprimento carcaça dos animais não-castrados foi maior que dos castrados $(134,70$ vs $125,86 \mathrm{~cm}$, respectivamente), o que indica maior desenvolvimento dos nãocastrados. Melhores resultados para comprimento de carcaça em animais não-castrados em comparação aos castrados também foi relatado por Restle et al. (1994). Houve interação categoria animal $\times$ condição sexual para comprimento de perna. Entre os animais jovens houve diferença no comprimento de perna favorável aos dos não-castrados, ao passo que nos superjovens não ocorreu diferença entre nãocastrados e castrados.

Não houve efeito de categoria animal na composição física da carcaça. No entanto, no estudo de Pacheco et al. (2005b), que compararam animais jovens e superjovens castrados com mesmo peso de abate e de carcaça, porém, com diferenças significativas de EGS $(3,22$ e 6,29 mm, respectivamente) e EGS $/ 100 \mathrm{~kg}$ de carcaça $(1,39$ e 2,71 mm), foi observada maior quantidade e participação de músculo e gordura na carcaça dos animais jovens e superjovens, respectivamente, resultando em maior relação músculo:gordura na carcaça proveniente de animais jovens.

As correlações entre as quantidades dos tecidos muscular, adiposo e ósseo e o peso de carcaça foram de $0,96(\mathrm{P}<0,05)$, $0,49(\mathrm{P}<0,05)$ e $0,92(\mathrm{P}<0,05)$, respectivamente (Tabela 3$)$. A maior correlação do tecido muscular e ósseo em relação ao tecido adiposo com o peso de carcaça é compreensível, uma vez que os animais ainda se encontravam em fase de crescimento. De acordo com Berg \& Butterfield (1976), o tecido ósseo apresenta maiores taxas de crescimento no estágio mais novo do animal, seguido pelo tecido muscular, enquanto o tecido adiposo é depositado no estágio mais avançado de desenvolvimento.

$\mathrm{Na}$ carcaça dos animais não-castrados, a quantidade e porcentagem de músculo é maior $(210,82 \mathrm{~kg}$ e $62,70 \%$ vs $162,32 \mathrm{~kg}$ e $58,40 \%$, respectivamente) que na dos animais castrados (Tabela 3). Os valores absolutos de gordura na carcaça foram semelhantes entre não-castrados e castrados (66,12 e 62,08 kg, respectivamente), porém quando foram expressos em relação ao peso de carcaça, houve maior participação de tecido adiposo na carcaça dos castrados (27,01 vs 22,60\%). Maior participação de tecido muscular em relação ao adiposo na carcaça de novilhos não-castrados também foi relatada por Restle et al. (1996) e Restle et al. (2000b). Em revisão, Seideman et al. (1982) relataram que o aumento da massa muscular em animais não-castrados é resultado da ação hormonal testicular (testosterona), ocasionando maior anabolismo de proteína e ,conseqüentemente, balanço positivo de nitrogênio corporal.

Os animais jovens não-castrados apresentaram maior quantidade de osso na carcaça em relação aos castrados da mesma categoria (Tabela 3 ). No entanto, quando este tecido foi calculado em relação ao peso de carcaça, esta diferença deixou de existir. É comprovado que, em animais em crescimento, o tecido ósseo é o de desenvolvimento mais intenso e tem com a finalidade de proteger o cérebro e servir na sustentabilidade do tecido muscular já em desenvolvimento (Hammond, 1959). A correlação do peso de carcaça e de músculo com o tecido ósseo foi de $0,92(\mathrm{P}<0,0001)$ e 0,87 $(\mathrm{P}<0,0001)$, respectivamente. Além da quantidade, Müller e Restle (1983) e Restle et al. (1996) ainda descreveram maior porcentagem de ossos na carcaça de animais não-castrados em relação aos castrados.

A relação músculo:osso foi similar entre não-castrados e castrados, uma vez que o aumento numérico $(\mathrm{P}>0,05)$ do tecido ósseo dos animais não-castrados foi acompanhado de maior deposição de músculo. A relação músculo:gordura foi maior nos animais não-castrados, o que evidencia a produção de carne magra nos animais não-castrados. 
Tabela 3 - Quantidades e porcentagens de músculo, gordura e osso na carcaça de novilhos jovens e superjovens

\begin{tabular}{|c|c|c|c|}
\hline Condição sexual & \multicolumn{2}{|c|}{ Categoria } & Média \\
\hline \multicolumn{4}{|c|}{ Músculo, kg } \\
\hline Castrados & $164,42 \pm 9,38$ & $160,23 \pm 8,14$ & $162,32 \pm 4,78 \mathrm{~B}$ \\
\hline Não-castrados & $227,26 \pm 6,83$ & $194,38 \pm 9,12$ & $210,82 \pm 4,94 \mathrm{~A}$ \\
\hline Média & $195,84 \pm 6,61$ & $177,30 \pm 7,07$ & \\
\hline Castrados & $60,50 \pm 5,79$ & $63,65 \pm 5,02$ & $62,08 \pm 2,94$ \\
\hline Não-castrados & $68,51 \pm 4,21$ & $63,72 \pm 5,63$ & $66,12 \pm 3,05$ \\
\hline Média & $64,50 \pm 4,08$ & $63,69 \pm 4,36$ & \\
\hline \multicolumn{4}{|c|}{ Osso, kg } \\
\hline Castrados & $34,00 \pm 2,21 b$ & $33,29 \pm 1,92 b$ & $33,65 \pm 1,13$ \\
\hline \multicolumn{4}{|c|}{ Músculo, \% } \\
\hline Castrados & $58,91 \pm 2,22$ & $57,88 \pm 1,93$ & $58,40 \pm 1,13 \mathrm{~B}$ \\
\hline Não-castrados & $62,49 \pm 1,62$ & $62,92 \pm 2,16$ & $62,70 \pm 1,17 \mathrm{~A}$ \\
\hline Média & $60,70 \pm 1,57$ & $60,40 \pm 1,67$ & \\
\hline \multicolumn{4}{|c|}{ Gordura, \% } \\
\hline Castrados & $26,34 \pm 2,27$ & $27,69 \pm 1,97$ & $27,01 \pm 1,16 \mathrm{~A}$ \\
\hline Não-castrados & $21,55 \pm 1,66$ & $23,65 \pm 2,21$ & $22,60 \pm 1,20 \mathrm{~B}$ \\
\hline Média & $23,94 \pm 1,60$ & $25,67 \pm 1,71$ & \\
\hline \multicolumn{4}{|c|}{ Osso, \% } \\
\hline Castrados & $14,75 \pm 0,89$ & $14,43 \pm 0,77$ & $14,59 \pm 0,45$ \\
\hline Não-castrados & $15,96 \pm 0,65$ & $13,45 \pm 0,87$ & $14,69 \pm 0,49$ \\
\hline \multicolumn{4}{|c|}{ Relação músculo:gordura } \\
\hline Castrados & $2,84 \pm 0,30$ & $2,64 \pm 0,26$ & $2,74 \pm 0,15 \mathrm{~B}$ \\
\hline Não-castrados & $3,36 \pm 0,22$ & $3,14 \pm 0,29$ & $3,25 \pm 0,16 \mathrm{~A}$ \\
\hline Média & $3,10 \pm 0,21$ & $2,89 \pm 0,23$ & \\
\hline \multicolumn{4}{|c|}{ Relação músculo+gordura:osso } \\
\hline Castrados & $6,62 \pm 0,28$ & $6,72 \pm 0,24$ & $6,67 \pm 0,14$ \\
\hline Não-castrados & $6,26 \pm 0,20$ & $7,07 \pm 0,27$ & $6,66 \pm 0,15$ \\
\hline Média & $6,44 \pm 0,20$ & $6,90 \pm 0,21$ & \\
\hline
\end{tabular}

A, B Médias seguidas de letras maiúsculas diferentes na coluna, para mesma característica, diferem $(\mathrm{P}<0,05)$ pelo teste $\mathrm{F}$.

a, b Médias seguidas por letras minúsculas diferentes, para mesma característica, diferem $(\mathrm{P}<0,05)$ pelo teste $t$.

\section{Conclusões}

Independentemente da categoria, jovem ou superjovem, animais não-castrados apresentam maiores pesos de abate e de carcaça, participação de músculos e relação músculo:gordura. A redução da idade de abate de 26 para 16 meses de idade promove aos animais nãocastrados deposição de gordura similar à de animais castrados.

\section{Literatura Citada}

ARTHAUD, V.H.; MANDIGO, R.W.; KOCH, R.M. et al. Carcass composition, quality and palatability attributes of bulls and steers fed different energy levels and killed at four ages. Journal of Animal Science, v.44, n.1, p.53-64, 1977.

BERG, R.T.; BUTTERFIELD, R.M. New concepts of cattle growth. Sydney: Sydney University Press, 1976. 240p.

CATON, J.S.; DHUYVETTER, D.V. Influence of energy supplementation on grazing ruminants: requirements and responses. Journal of Animal Science, v.75, p.533-542, 1997. 
CHAMPAGNE, J.R.; CARPENTER, J.W.; HENTGES, J.F. et al. Feedlot performance and carcass characteristics of young bulls and steers castrated at four ages. Journal of Animal Science, v.29, n.6, p.887-890, 1969.

DIKEMAN, M.E.; REDDY, G.B.; ARTHAUD, V.H. et al. Longissimus muscle quality, palatability and connective tissue histological characteristics of bulls and steers fed different energy levels and slaughtered at four ages. Journal of Animal Science, v.63, p.92-101, 1986 .

GERRARD, D.E.; JONES, S.J.; ABERLE, E.D. et al. Collagen stability, testosterone secretion and meat tenderness in growing bulls and steers. Journal of Animal Science, v.65, p.1236$1242,1987$.

HAMMOND, J. Avances en fisiologia zootecnia. Zaragoza: Acribia, 1959. 200p.

HANKINS, P.; HOWE, P.E. Estimation of composition of beef carcasses and cuts. Washington, D.C.: United States Department of Agriculture (USDA), 1946. (Technical Bulletin, 926).

KUSS, F.; BARCELlOS, J.O.J.; LÓPEZ, J. et al. Componentes nãointegrantes da carcaça de novilhos não-castrados ou castrados terminados em confinamento e abatidos aos 16 ou 26 meses de idade. Revista Brasileira de Zootecnia, v.37, n.10, p.18291836,2008

LOWMAN, B.G.; SCOTT, N.; SOMERVILLE, S. Condition scoring beef cattle. Edinburgh: East of Scotland College of Agriculture, 1973. 8p.

MORAIS, C.A.C.; FONTES, C.A.A.; LANA, R.P. et al. Influência da monensina sobre o rendimento de carcaça e de seus cortes básicos e outras características, em bovinos castrados e não castrados. Revista Brasileira de Zootecnia, v.22, n.1, p.72-80, 1993

MORGAN, J.B.; WHEELER, T.L.; KOOHMARAIE, M. et al. Effect of castration on myofibrillar protein turnover, endogenous proteinase activities, and muscle growth in bovine skeletal muscle. Journal of Animal Science, v.71, p.408-414, 1993 b.

MORGAN, J.B.; WHEELER, T.L.; KOOHMARAIE, M. et al. Meat tenderness and the calpain proteolytic system in Longissimus muscle of young bulls and steers. Journal of Animal Science, v.71, p.1471-1476, 1993a

MÜLLER, L. Normas para a avaliação de carcaças e concurso de carcaças de novilhos. 2.ed. Santa Maria: Imprensa Universitária, 1987. 31p.

MÜLLER, L. Técnicas para determinar la composición de la canal. Memória de la Associación Latinoamericana de Producción Animal. Guadalajara: 1973. p.75.

MÜLLER, L.; RESTLE, J. Carcass characteristics of steers and young bulls. In: EUROPEAN CONGRESS OF MEAT RESEARCH WORKERS, 29., 1983, Parma. Proceedings... Parma: 1983. p. $530-535$.

PACHECO, P.S.; SILVA, J.H.S.; RESTLE, J. et al. Características da carcaça de novilhos jovens e superjovens de diferentes grupos genéticos. Revista Brasileira de Zootecnia, v.34, n.5, p.1666-1677, 2005a.
PACHECO, P.S.; RESTLE, J.; SILVA, J.H.S. Composição física da carcaça e qualidade da carne de novilhos jovens e superjovens de diferentes grupos genéticos. Revista Brasileira de Zootecnia, v.34, n.5, p.1691-1703, 2005b.

PURCHAS, R.W.; BURNHAM, D.L.; MORRIS, S.T. Effects of growth potential and growth path on tenderness of beef Longissimus muscle from bulls and steers. Journal of Animal Science, v.80, p.3111-3221, 2002.

RESTLE, J.; ALVES FILHO, D.C.; FATURI, C. et al. Desempenho na fase de crescimento de machos bovinos inteiros ou castrados de diferentes grupos genéticos. Revista Brasileira de Zootecnia, v.29, n.4, p.1036-1043, 2000a.

RESTLE, J.; GRASSI, C.; FEIJÓ, G.L.D. Características das carcaças e da carne de bovinos inteiros ou submetidos a duas formas de castração, em condições de pastagem. Revista Brasileira de Zootecnia, v.25, n.2, p.334-343, 1996.

RESTLE, J.; GRASSI, C.; FEIJÓ, G.L.D. Características de carcaça de bovinos de corte inteiros ou castrados em diferentes idades. Pesquisa Agropecuária Brasileira, v.29, n.10, p.1603-1607, 1994.

RESTLE, J.; VAZ, F.N. Aspectos quantitativos da carcaça de machos Hereford, inteiros e castrados, abatidos aos quatorze meses. Pesquisa Agropecuária Brasileira, v.32, n.1, p.1091-1095, 1997.

RESTLE, J.; VAZ, F.N. Eficiência e qualidade na produção de carne bovina. In: REUNIÃO ANUAL DA SOCIEDADE BRASILEIRA DE ZOOTECNIA, 40., 2003, Santa Maria. Anais... Santa Maria: Sociedade Brasileira de Zootecnia. [2003]. (CD-ROM).

RESTLE, J.; VAZ, F.N.; FEIJÓ, G.L.D. Características de carcaça de bovinos de corte inteiros ou castrados de diferentes composições raciais Charolês x Nelore. Revista Brasileira de Zootecnia, v.29, n.5, p.1371-1379, 2000b.

STATISTICAL ANALYSIS SYSTEM - SAS. User's guide: statistics. versão 8.1. 4.ed., v.2, Cary: SAS Institute, 2000

SEIDEMAN, S.C.; CROSS, H.R.; OLTJEN, R.R. et al. Utilization of the intact male for red meat production: a review. Journal of Animal Science, v.55, n.4, p.826-841, 1982.

SMITH, N.E.; BALDWIN, R.L. Effects of breed, pregnancy, and lactation on weight of organs and tissues in dairy cattle. Journal of Dairy Science, v.57, n.9, p.1055-1060, 1973.

TOWNSEND, M.R.; RESTLE, J.; PASCOAL, L.L. et al. Características qualitativas das carcaças de novilhos e vacas terminadas em confinamento. In: REUNIÃO ANUAL DA SOCIEDADE BRASILEIRA DE ZOOTECNIA, 27., 1990 , Campinas. Anais... Campinas: Sociedade Brasileira de Zootecnia, 1990. p.361.

VAZ, F.N.; RESTLE, J.; FEIJÓ, G.L.D. et al. Qualidade e composição química da carne de bovinos inteiros ou castrados de diferentes grupos genéticos Charolês x Nelore. Revista Brasileira de Zootecnia, v.30, n.2, p.518-525, 2001.

VAZ, F.N.; RESTLE, J.; QUADROS, A.R.B. et al. Características da carcaça e da carne de novilhos e de vacas de descarte Hereford, terminados em confinamento. Revista Brasileira de Zootecnia, v.31, n.3, p.1501-1510, 2002 (supl.). 